\title{
Aboriginal Incarceration in Canada since 1978: Every Picture Tells the Same Story ${ }^{1}$
}

\section{Revision}

Corresponding author:

Julian V. Roberts, Faculty of Law, University of Oxford

Julian.roberts@crim.ox.ac.uk

Co-author

Andrew Reid, School of Criminology

Simon Fraser University

\begin{abstract}
Sentencing in Canada is beset by many problems yet one weakness stands above the rest: the disproportionately high rates of Aboriginal incarceration. This article documents current and historical trends in levels of Aboriginal incarceration at the provincial/territorial and federal levels since 1978. We pay particular attention to the years following two important Supreme Court judgments (in 2001 and 2012) which directed courts to use custody with greater restraint when sentencing an Aboriginal offender. The primary data derive from the annual Adult Correctional Services (ACS) Survey conducted by Statistics Canada. In 2014, Aboriginal persons accounted for just over one quarter of all provincial and territorial admissions, significantly higher than the percentage recorded in 1978 (16\%). In fact, over the last 20 years all jurisdictions save one have experienced an increase in the percentage of Aboriginal admissions to provincial correctional institutions. Despite judgments from the Supreme and provincial courts of appeal, and a number of other remedial interventions such as the creation of so-called
\end{abstract}


'Gladue' courts and an alternate form of custody served in the community, the problem of Aboriginal over-incarceration has worsened, not improved.

Key Words: imprisonment, Aboriginal peoples, Indigenous peoples, sentencing 
Sentencing in Canada is beset by many problems, including disparity, the absence of a commission to provide consistent research and guidance, little transparency, a general over-use of custody as a sanction, and low levels of public confidence. Yet one weakness stands above the rest: the high number of Aboriginal persons in prison. Awareness of the problem is relatively recent: Aboriginal incarceration was not identified as a problem until a seminal 1984 report regarding sentencing (Government of Canada 1984). Courts, in contrast, have long grappled with the question of whether the conventional approach to sentencing was suitable for Aboriginal offenders. ${ }^{2}$ Almost 30 years have passed since the report of the Standing Committee on Justice and Solicitor General (Daubney 1988) acknowledged the problem and proposed some remedies. A number of subsequent reports (e.g., the Royal Commission on Aboriginal Peoples [RCAP] 1996) and Commissions of Inquiry (e.g., RCAP and the Ipperwash Inquiry in 2007) also addressed the issue and advanced various solutions. Most recently, (in 2015), the Truth and Reconciliation Commission further underlined the scale of the problem, while suggesting relatively limited solutions (Canada 2015b). ${ }^{3}$

Despite this succession of official reports and academic commentary, remedial reforms implemented to date have been few and modest in scale. The only legislative attempt to reduce the use of incarceration for Aboriginal offenders emerged in 1996 when Parliament codified special consideration for Aboriginal offenders as part of an omnibus sentencing reform Act, Bill C-41 (see Daubney and Parry 1999; Murdocca 2013). Section 718 states that: 'A court that imposes a sentence shall also take into consideration the following principles:...

(e) 'all available sanctions other than imprisonment that are reasonable in the circumstances should be considered for all offenders, with particular attention to the circumstances of Aboriginal offenders'.

Section 718.2(e) was subsequently the basis of litigation to the Supreme Court as well as the subject of much academic commentary. ${ }^{4}$ This legislative provision, in turn, led to several 
Supreme Court judgments (including Gladue and Ipeelee) which were specifically intended to ameliorate the problem of Aboriginal over-incarceration. In Gladue for example, the Court took the view that a different methodology was appropriate when sentencing an Aboriginal offender, one which would be more likely to result in a noncustodial option (although ultimately the Court upheld the term of imprisonment on the offender). Bill C-41 also created the conditional sentence of imprisonment (CSI), a community-based form of custody. While not explicitly designed to address the issue of Aboriginal incarceration, there was an expectation that Aboriginal defendants in particular would benefit from the new sanction, and that this would contribute to a reduction in Aboriginal admissions to provincial custody. ${ }^{5}$ Have these reforms succeeded? Research documenting trends in the use of CSIs indicates that Aboriginals have not experienced the benefit originally expected. Most recently, Reid (2016) explored trends in the use of the sanction among Aboriginal and non-Aboriginal offenders across 10 provincial and territorial jurisdictions. In the combined jurisdiction trend, only minor differences were noted between the two offender groups and Aboriginals were found to have experienced a lower use of the sanction in the most recent four-year period (2009 to 2013). More detailed analyses found that several jurisdictions where Aboriginal incarceration had historically been among the most overrepresented, had lower use of CSIs with Aboriginals. Because no research has empirically evaluated the impact of the CSI on Aboriginal imprisonment, however, a more detailed consideration of recent imprisonment trends is warranted.

An examination of trends in the use of custody is timely from several perspectives. First, a generation has now passed since the landmark sentencing reform of 1996 (Bill C-41). Second, the last scholarly exploration of Aboriginal and non-Aboriginal correctional trends was published over a decade ago (Roberts and Melchers 2003). Evaluations of the 1996 reform have 
been very limited in scope (e.g., Welsh and Ogloff 2008), and there has been no recent historical analysis of trends. Third, recent legislative amendments (e.g., Bill C-10) restricting alternatives to custody appear to conflict with efforts aimed at reducing the use of incarceration for Aboriginal offenders (Rudin 2013). Fourth, the Truth and Reconciliation Commission recently called for Canada to eliminate the over-representation of Aboriginal people in custody 'over the next decade’ (Canada 2015a: 219). Whether this ambitious and laudable objective is attainable depends upon knowing the true scale of the problem. Finally, the current federal government, (elected in 2016), has expressed a clear intention to address the complex and to date, seemingly intractable problem of the high rate of Aboriginal Canadians incarceration.

\section{A Global Problem}

Aboriginal incarceration is a problem confronting many jurisdictions (see Cuneen 2014; Jeffries and Stenning 2014). Visible and indigenous minorities account for disproportionate numbers of admissions to custody in all western nations - a fact that has been documented for years now (e.g., Tonry 1997). Aboriginal persons in Australia and New Zealand, for example, have been found to be disproportionately represented in correctional statistics (Jeffries and Bond 2012a; Jeffries and Bond 2012b; Jeffries and Stenning 2014). In Australia, age-standardized rates of Aboriginal incarceration have been found to be approximately 15 times higher than that of non-Aboriginals. While Aboriginal people constitute just 3\% of the estimated resident population, they represent $25 \%$ of the total population incarcerated (Jeffries and Stenning 2014). Aboriginal over-incarceration is also apparent in New Zealand. In 2015, New Zealand's Māori population stood at just $15 \%$ while $50 \%$ of all sentenced prisoners were identified as belonging to that ethic group (New Zealand Department of Corrections 2015; Statistics New Zealand 2015). The Canadian experience therefore has relevance for several other western jurisdictions. 


\section{Overview of Article}

This article documents current levels of Aboriginal admissions to custody and reviews changes in the volume and proportion of Aboriginal admissions since 1978. Roberts and Melchers (2003) explored sentencing trends for Aboriginal and non-Aboriginal admissions up until 2001; this article brings that analysis up to date. The analysis includes the new jurisdiction of Nunavut, summarizes trends regarding remand detention, and also explores for the first time the limited federal statistics currently available. We pay particular attention to the years following important Supreme Court judgments in 2001 and 2012. Our purpose is primarily descriptive rather than explanatory; explaining the trends nationally and regionally will take a more fine-grained analysis. The first step in understanding the phenomenon is to place the current position within an historical context. The article concludes by briefly proposing remedial options. Finally, it is important to note that the correctional statistics presented and discussed here aggregate First Nations individuals within a single category 'Aboriginal'. This is clearly an oversimplification of the diverse communities of indigenous peoples across Canada, and indeed the variation within communities (e.g., urban versus rural). A clear next step for researchers is to understand the differential impact that criminal justice has upon diverse communities, but this is for the future. Our purpose is to take stock of the historical trends to date on a national level.

\section{Method}

\section{Data Sources}

Ideally, the over-incarceration for Aboriginal Canadians (or any other group) would be established by comparing annual population statistics to correctional statistics such as annual admissions, or average prison or community supervision populations. This research strategy has been adopted in the limited comparative analyses of national trends (e.g., Walmsley 2015). However, the absence of reliable, annual Aboriginal population statistics precludes such an 
approach in Canada. We present limited population-based comparisons for three years, and then focus on annual admissions to custody, comparing trends for Aboriginal and non-Aboriginals. We document the principal indicator of Aboriginal incarceration, namely the percentage of all such admissions involving an Aboriginal person. ${ }^{6}$ Yet it is also necessary to explore the absolute numbers of Aboriginal and non-Aboriginal admissions, since a higher increase in non-Aboriginal admissions (relative to Aboriginal offenders) would necessarily reduce the percentage of Aboriginal offenders.

The principal source of data is the annual Adult Correctional Services (ACS) Survey, conducted by Statistics Canada. Our focus is upon provincial sentenced admissions to custody. ${ }^{7}$ Although the ACS includes some data on admissions to federal penitentiaries, almost all (96\%) of terms of imprisonment in Canada are under two years, and are served in provincial and territorial institutions. The consequence of this is that remedial efforts directed at reducing the number of Aboriginal offenders admitted to federal custodial facilities would have very little impact on the total population in custody. Nevertheless, we analyse the limited federal data that are currently available.

\section{Ambit of Inquiry}

The historical analysis excludes statistics relating to custodial remand or custody involving youth, although we begin by summarizing the latest data regarding Aboriginal and non-Aboriginal remand populations. This accomplished the analysis focus on sentenced admissions and populations. Although remanded prisoners constitute an important source of Canada's custodial population, the decision to remand is very different from the decision to sentence an individual to custody and therefore worthy of independent consideration. Similarly, although Aboriginals are also over-represented in custodial populations of young offenders ${ }^{8}$, 
differences between adult and youth sentencing processes justify separate analyses. Finally, the analysis does not differentiate male and female offenders. Subsequent research should examine

these groups separately, as there is clear evidence that gender interacts with sentencing decisions and in particular the application of section 718.2(e) (see discussion in Williams 2007; Balfour 2013).

\section{Results}

\section{Remand}

Although the principal focus of this article is upon sentenced admissions, it would be a mistake to overlook the remand prison population, as Aboriginal overrepresentation is a problem here too. Table 1 summarises Aboriginal and non-Aboriginal admissions to provincial and territorial remand over the period 2000-01 to 2014-15. As can be seen, in the most recent year for which data are available, Aboriginal persons accounted for one quarter of remand admissions. Moreover, in a pattern which will echo our findings with respect to sentenced admissions, the over-representation of Aboriginal persons in the remand admission statistics has become worse over the past decade. Thus in 2004-05, 16\% of remand provincial/ territorial admissions were aboriginal, rising to the 25\% statistic reported a decade later (Table 1). Table 2 also confirms a pattern which emerges with respect to sentenced admissions: Aboriginal admission rates vary greatly across the country, being highest in Nunavut, the Northwest Territories, Saskatchewan, and the Yukon (Table 2). In short, the problem of the high number of First Nations peoples in Canada's prisons is by no means restricted to the sentencing stage; this finding carries important consequences for remedial solutions. At this point we turn to the latest and historical trends with respect to sentenced admissions.

Insert Tables 1 \& 2 here 


\section{Canada-wide Trends: The Big Picture}

As noted in the introduction, annual population based statistics are unavailable at present and for this reason we shall shortly focus on the relative proportions of Aboriginal and nonAboriginal offenders in prison populations. However, Table 3 summarises population-based comparisons for three specific years, 2001, 2006 and 2011. This Table may be summarised in the following way. First, the Aboriginal admission ratio -- namely the population based proportion of Aboriginal admissions compared to the proportion of non-Aboriginal admissions - was 5.68 in the first of the three years. This means that Aboriginal persons were almost six times more likely to be admitted to prison than non-Aboriginal Canadians, based upon their general population statistics. Second, this over-representation of Aboriginal persons was worse in 2006 (rising to 7.82) and worst in the most recent year (9.12). This deteriorating picture is consistent with the trends emerging from non-population based statistics that we will shortly describe and discuss in more detail. Third, there was great variation in admission rates and rate ratios among the provincial/territorial jurisdictions. In 2011, for example, the Aboriginal rate ratio was 2.93 in Newfoundland and Labrador. In Saskatchewan, however, the rate ratio was 19.95, meaning Aboriginals were close to 20 times more likely to be admitted to prison than non-Aboriginals in that province.

Before leaving the population data we can note that the latest statistics (from the National Household Survey, NHS) revealed that in 2011, 4.3\% of the total Canadian population classified themselves as Aboriginal. ${ }^{9}$ We begin by comparing the proportion of Aboriginal admissions in the latest data (2014-15) to the earliest available year (1978-79) before focussing on the last 15 years. Table 4 provides the percentage of provincial and territorial custodial admissions in three one-year snapshots, 1978-79, 2000-01, and 2014-15. As can be seen, in the most recent year, 
Aboriginal persons accounted for just over one quarter (26\%) of all admissions, significantly higher than the percentage recorded in 1978-79 (15\%) or 2000-01 (15\%).

\section{Table 4 about here}

Before delving into trends in the intervening years, we can conclude that despite the remedial initiatives noted earlier, and notwithstanding the heightened public ${ }^{10}$ and professional awareness of the problem, Aboriginal over-incarceration persists in Canada. Indeed, the problem has worsened over the years. The proportion of Aboriginal admissions to provincial custody in 2014-15 was the same or higher than 2000 in all jurisdictions. The average percentage of Aboriginal admissions over the most recent decade (2005-2014) was 25\%, significantly higher than the average recorded in the first decade included in the analysis (1978-1987: 13.7\%).

The second observation is that the specific jurisdictions reporting the highest rates of Aboriginal admissions were the same in both time periods. Nunavut, which did not exist in 1978, reported a 100\% Aboriginal admission rate in 2013-2014, with the Northwest Territories almost the same (87\%). Thereafter, Saskatchewan and Manitoba recorded the highest Aboriginal incarceration rates, at 77\% and 76\% respectively. In contrast, Quebec and Prince Edward Island reported very small percentages of Aboriginal admissions (both 3\%). The ranking of jurisdictions in terms of the proportion of Aboriginal admissions remained stable, but the overall magnitude of the problem has not: With the exception of Prince Edward Island, all provinces for which comparative data are available reported a higher rate in the most recent time period (Table 4). Figure 2 summarizes the proportion of Aboriginal sentenced admissions over the entire period, from 1978 to 2014, in the provinces and territories. As can be seen, the proportion of Aboriginal admissions was relatively stable for the first 30 years, varying little from a mean of 
$17 \%$, and never exceeding $19 \%$. Over the past decade, however, the extent of over-incarceration became worse, rising to the current high of $26 \%$ of all sentenced admissions.

\section{Figures 1 and 2 about here}

\section{Canada-wide Trends: 2000-2014}

Several conclusions may be drawn from the national trends. First, over the most recent four years (2011-14), the volume of both Aboriginal and non-Aboriginal admissions declined. Non-Aboriginal admissions fell 25\% from 60,638 in 2011 to 45,737 in 2014. The volume of Aboriginal admissions to custody also declined - by $32 \%$ from 24,161 to 16,309 . Yet the proportion of Aboriginal admissions was significantly higher at the end of the 15-year period. The percentage in the most recent quadrennial (2011-14) was 27\%, notably higher than in the first four-year period (16\%; see Table 3). The trend is represented graphically in Figure 2.

\section{Table 5 about here}

Table 5 provides the total period average for both Aboriginal and non-Aboriginal admissions. The period average constitutes an anchor with which to understand and contextualise the latest trends. Across the jurisdictions captured by this analysis, by 2014, non-Aboriginal admissions had declined by 19\% relative to the period average. In contrast, the 2014 data for Aboriginal admissions reveal a decline of only 2\%. Total committals to custody were down, largely due to declining crime rates, yet there is no evidence that Aboriginals benefitted from interventions designed to reduce admissions for that category of offender.

\section{Federal Trends}

The limited federal statistics present a comparable picture. Aboriginal ${ }^{11}$ admissions have accounted for an increasing percentage of federal admissions (see Figure 1). In the earliest year for which federal data are available (1982-83), Aboriginal persons accounted for 9\% of federal 
warrant of committal admissions. This percentage rose steadily thereafter, reaching an historic high of $19 \%$ percent in 2006-07. The most recent data pertain to $2008-09$, and reveal that $18 \%$ of the admissions involved an Aboriginal person. The total volume of admissions tells the same story. In 2009-10 there were 2,919 Aboriginal persons in the federal correctional population (Public Safety Canada 2015: Table C-16). The number has increased since then, reaching 3,660 in 2014-15, the most recent year for which data are available (Public Safety Canada 2016: Table C-16). This represents a $25 \%$ increase in a five-year period.

Figure 2 about here

\section{Trends of Selected Provinces and Territories: 2000-2014}

At this point we examine selected jurisdictions in more detail, focusing on the most populous provinces and those which have historically experienced the highest rates of Aboriginal incarceration. Although Alberta has a relatively high rate of Aboriginal incarceration, we do not present data for this province due to data limitations during the period covered by this article. Specifically, data were not provided by Alberta institutions to the ACS for years prior to 2005-06 and the period 2012-13 to 2013-14. That said, the limited data available suggest that the national trends are replicated in Alberta. In 1978, only one quarter of provincial admissions were Aboriginal. In the most recent year for which Alberta data are available (2011), Aboriginal admissions accounted for $43 \%$ of total admissions.

\section{a) Saskatchewan}

As noted in Table 4, Saskatchewan is the province which currently and historically has experienced the highest rate of Aboriginal incarceration: in 1978, almost two-thirds (61\%) of admissions were Aboriginal. Table 6 shows that the percentage of Aboriginal admissions was significantly higher than this throughout the most recent period covered (2000-14). The 
proportion of admissions involving an Aboriginal person remained stable over the period. As can be seen, the percentage has not dropped below 77\% between 2000 and 2014. However, the volume of Aboriginal admissions has increased during the past decade. The pattern was little different for non-Aboriginal admissions, which were significantly higher in 2014 than a decade earlier. The trend in Saskatchewan is surprising; given the traditionally high rate of Aboriginal admissions and the endorsement of s. 718.2(e) by the Saskatchewan Court of Appeal ${ }^{12}$, one might have expected the provision to have lowered the rate of Aboriginal admissions, relative to non-Aboriginal offenders. In terms of trends relative to the period average, until the most recent year, non-Aboriginal and Aboriginal admissions increased at approximately the same rate. In 2014, however, the former rose further while the latter declined.

\section{Table 6 about here}

\section{b) Manitoba}

Manitoba is the other province which has long experienced particularly high Aboriginal incarceration rates. The trends in this province also reveal no evidence of progress in reducing Aboriginal incarceration. In 1978, Aboriginal admissions accounted for half of all admissions to provincial custody in the province. By 2000 this had risen to 64\%, and rose still higher to $76 \%$ by the most recent year (2014). As with Saskatchewan, the Manitoban trend has been stable, varying little over the entire period. In terms of volumes of committals to custody, Aboriginal admissions have actually increased, and at a faster rate than non-Aboriginals. Using the total period average as an anchor, in 2014, Aboriginal admissions were 51\% higher; in contrast, nonAboriginal admissions were only 23\% higher (see Table 7).

Table 7 about here

\section{c) Ontario}


Canada's most populous province accounts for the second highest total number of Aboriginal admissions to custody. As can be seen in Table 8, although only $12 \%$ of the Ontario admissions were Aboriginal in 2014, this represents almost 3,000 individuals. ${ }^{13}$ In addition, and consistent with the national trend, Aboriginal admissions have risen over the period, from $9 \%$ in 2000 to $12 \%$ in 2014 . Relating the latest years to the period average reveals a significant decline in non-Aboriginal admissions, down 22\% from the average. In contrast, Aboriginal admissions in 2014 had declined by only 5\%. Once again, Aboriginal persons seem worse off than nonAboriginal offenders.

\section{Table 8 about here}

\section{d) British Columbia}

The trends in British Columbia are the worst. In 1978, 15\% of provincial admissions to custody in BC were Aboriginal; this statistic rose to 20\% in 2000. By 2014 this statistic had more than doubled, to 34\%. Table 9 summarizes the trends. The average over the most recent four years was $33 \%$, up significantly from the $20 \%$ average across the first four years of the series (2000-04). As elsewhere in Canada, the percentage of Aboriginal admissions was significantly higher at the conclusion of the period in which a number of initiatives were launched to ameliorate the problem. Comparing the two categories of offenders with reference to their period averages reveals that by 2014 non-Aboriginal admissions were down by 7\%. Over this period, Aboriginal admissions, in contrast, were $37 \%$ higher in 2014. The divergent patterns become even more apparent by comparing 2014 to 2000. Aboriginal admissions increased by 65\%, from 1,931 to 3,193 admissions. Non-Aboriginal admissions, in contrast, actually declined by $17 \%$, from 7,589 to 6,325 (Table 9).

Table 6 about here 


\section{e) Newfoundland and Labrador}

Table 10 summarizes trends for Newfoundland and Labrador. In 1978, Aboriginal admissions to custody represented only 3\% of total admissions. This percentage then increased, and by 2000 this statistic had risen to 7\% of admissions. This then rose steeply to the current level of 32\%. The absolute numbers of individual offenders may be relatively small (360), yet it represents a striking increase over the 70 Aboriginal admissions recorded in 2000. Again, comparisons to the period average are revealing. The volume of non-Aboriginal admissions in 2014 was at the period average, having declined since a period high in 2010. In contrast, Aboriginal admissions in 2014 had more than doubled from the period average.

\section{Table 10 about here}

\section{f) Nunavut}

We conclude our review of select jurisdictions by noting trends in the territory created at the beginning of the period covered by our analysis. In light of the general Nunavut population it is unsurprising that in every year since 2001 Aboriginal persons accounted for all admissions to custody (see Table 11). What is striking about the Nunavut statistics is the increasing absolute number of Aboriginal admissions - rising from an average of 290 in the first four years of the period (2001-2005) to 470 in the most recent four-year period (2011-2014). This represents an increase of $62 \%$. With respect to the period average, 2014 admissions were 32\% higher.

\section{Table 11 about here}

\section{Summary and Discussion}

We can summarise the trends described in this article in the following propositions:

- As of 2014-2015, the most recent year for which correctional data are available, Aboriginal Canadians represented a disproportionate number of admissions to provincial, 
territorial and federal custody. While they constitute only approximately $4 \%$ of the general population, they account for almost $30 \%$ of all sentenced admissions to custody (federal and provincial/territorial combined).

- Compared to 1978, the first year for which reliable correctional statistics are available, Aboriginal persons accounted for a significantly higher percentage of custodial admissions in 2014.

- Trends over the most recent decade (2005-14) indicate that the problem of Aboriginal incarceration is getting worse, not better.

- The picture varies across jurisdictions. In some provinces such as British Columbia, the volume of Aboriginal admissions was strikingly different and higher than non-Aboriginal admissions.

- The deterioration of the problem has occurred, paradoxically, during a period which has seen a number of remedial initiatives launched, and a series of important judgments from the Supreme Court of Canada.

\section{Explaining the Increase in Over-Representation}

The trends seem clear enough - Aboriginal over-incarceration has become worse in most provinces and territories over the past decade, even though the total volume of Aboriginal and non-Aboriginal admissions declined. Yet the explanations for these trends remain elusive. A wide range of explanations need to be considered. Some of these relate to demographic differences in the Aboriginal and non-Aboriginal communities. Others relate to the differential engagement of Aboriginal communities in crime and criminal justice, and are likely to give rise to remedial reforms. For example, to what extent are mandatory sentencing provisions and restrictions on the use of conditional sentences more likely to affect Aboriginal defendants? An 
effective response can only emerge from a clearer understanding of the factors driving the use of incarceration for Aboriginal offenders.

\section{A Global Failure?}

It is important to note that Canada is not alone in having failed to ameliorate the problem. A closer look at trends in Australia reveals an extraordinarily similar picture to the Canadian experience. The Royal Commission into Aboriginal Deaths in Custody appointed by the Australian Government in 1987 triggered the collection of national statistics on the rate of Aboriginal and Torres Strait Islander incarceration. The Commission set out to investigate the death of dozens of Indigenous persons in custody but ended up focusing on the larger issue of Indigenous over-representation in the criminal justice system. In the final report, 339 recommendations were made, many of which concerned criminal justice system responses. Among these, several were aimed at the sentencing process including the development of alternative sanctions to custody (Johnston 1991). Over the years, many diversion programs (both generic and Indigenous-specific) have also been developed, including Aboriginal courts (e.g., Closing the Gap Clearinghouse 2013: Appendix B). Despite these remedial efforts, national trends in the imprisonment of Indigenous people in Australia remain comparable to that of Canada. Although an increasing population size has contributed to a rise in the number of Indigenous prisoners, the rate of imprisonment has also seen a dramatic increase. The rate of Indigenous imprisonment rose by 64\% between 2000 and 2012 (Closing the Gap Clearinghouse 2013: 3). That is in sharp contrast to a 5\% increase in the non-Indigenous rate during the same period.

Specific jurisdictions in Australia have revealed trends similar to the national pattern. Nearly a decade after the final report of the Royal Commission (Johnston 1991), the Queensland 
Aboriginal and Torres Strait Islander Justice Agreement (in 2000) formed part of a response to a 1997 resolution between the Queensland Government and Aboriginal and Torres Strait Islander community representatives. The Agreement set out a long-term goal of reducing the rate by which Aboriginal and Torres Strait Islander people came into contact with the criminal justice system to 'at least the same rate as other Queenslanders' (Queensland Government 2001: 11). More specifically, the objective was 'a reduction by 50\% in the rate of Aboriginal and Torres Strait Islander peoples incarcerated in the Queensland criminal justice system by the year 2011' (Queensland Government 2001: 11). In a recent assessment of the 2000 Agreement, the government acknowledged that these objectives were not met. In fact, the proportion of Aboriginal persons incarcerated rose from 23\% to 29\% during the ten-year period (Queensland Government 2011: 10).

New Zealand's experience is comparable. In 1985 a number of legislative amendments were introduced in an effort, at least in part, to curtail the over-incarceration of Māori. Specifically, the Criminal Justice Act (1985) increased the number of available communitybased sentences. It also introduced section 16 (subsequently repealed in 2002) which allowed an offender to request the court hear witnesses who may speak about the way that cultural or ethnic background may have been related to the commission of the offence, and the way that it might help avoid future offending (New Zealand Ministry of Justice 1997). Trends in the use of incarceration among Māori, however, have not improved over the years. Between 1983 and 2013, the number of Māori starting a prison sentence increased from 2,879 to 4,311 while the number of Europeans decreased from 2,419 to 2,409 (New Zealand Department of Corrections 2013: 4). That represented an increase in the proportion of Māori starting a prison sentence from $47 \%$ to $56 \%$ during that 30 -year period. 
These examples demonstrate striking similarities between the historical trends of Aboriginal incarceration in different western countries; despite numerous remedial initiatives, the problem of Aboriginal over-incarceration has been getting worse.

\section{The Failure to Date in Canada}

What is responsible for the high (and rising) rates of Aboriginal admissions to custody during the period which encompassed important Supreme Court judgements affirming the significance of Aboriginality at sentencing? Several explanations may briefly be offered for the failure of remedial efforts, principally with a view to stimulating further explanatory research. One possibility is that the statutory provision and the subsequent direction of the Court has been inadequately implemented by courts (see Balfour 2012; Pelletier 2001). It is possible that defence advocates have been slow to bring this provision (and the related judgments) to the attention of courts at sentencing - business as usual, in other words. Writing for the Ipperwash Inquiry, Rudin (2008) suggested that courts were not receiving the information necessary for them to implement the direction in Gladue. If this were the case, it would help to explain the failure to address the problem. This explanation would seem more plausible during the early years following the Gladue decision, and less likely to explain the more recent upswing in Aboriginal incarceration.

A more radical possibility is that the provision has been systematically invoked in sentencing submissions and subsequently applied by judges across Canada, but the problem is beyond the power of the courts to remedy. This critique has been cited by scholars for many years now (e.g., LaPrairie 1990). A final possible explanation is that the relatively modest nature of section 718.2(e) means that it was never likely to achieve the sea change in the sentencing of Aboriginal persons that would be necessary to significantly reduce the over-incarceration 
problem. Yet none of these explanations can account for the worsening of the problem in recent years.

Our preliminary conclusion would be that the federal and provincial governments need to consider all three levels of explanation. First, a much greater effort is needed to ensure consistent application of the principles enunciated by the Supreme Court in Ipeelee and related cases.

Second, a more ambitious sentencing methodology is required, one which goes further than simply encouraging courts to consider alternatives (see below). Finally, neither of these solutions is likely to prove as successful as a holistic approach to addressing the social conditions giving rise to crime and convictions in First Nations communities.

\section{Alternative Approaches to Reducing the Use of Custody for Aboriginal Canadians}

What other legislative remedies exist for this intractable problem? It is beyond the scope of this article to provide a comprehensive review of remedial options for Canada. However, some potential solutions may be noted. The most radical approach would involve creation of a separate sentencing regime for Aboriginal offenders. This solution was recommended by RCAP many years ago and from time to time has been promoted by academics and advocates in the field. The strength of this approach is that it would permit a de nouveau, comprehensive approach to sentencing in cases involving Aboriginal offenders one which would return to first principles and could be conceived and developed in consultation with First Nations across Canada. At present, courts must grapple with applying sentencing objectives and principles designed for non-Aboriginal offenders.

A separate sentencing code for Aboriginal offenders may well ultimately reflect a very different set of objectives, principles and dispositions. For example, s. 718.1 identifies proportionality as the fundamental principle of sentencing. This principle derives from a censure- 
based retributive sentencing philosophy (von Hirsch 1996). Yet can we assume that it is equally applicable to First Nations across Canada? Might the emphasis on proportionality prevent courts from giving sufficient weight to s. 718.2(e)? Balfour (2013: 98) for example, argues that 'judges remain tied to ... punishment proportionate to the seriousness of the offence' with the consequence that sentencing reforms such as s. 718.2(e) have been rendered ineffective (see also Murdocca, 2013, pp. 58-60). There is a potential conflict between a principle which emphasises the components of culpability and harm as determinants of sentence severity and one which directs courts to consider a categorical factor such as Aboriginality or gender which courts may perceive as being unrelated to these components. Similarly, the range of sentencing options currently deployed by courts may not reflect the penal objectives of Aboriginal communities.

A second, more modest approach would involve simply strengthening the current wording of the statutory provision relating to the use of custody. The language of s. 718(2)(e) represents a relatively mild injunction to courts, simply to 'pay particular attention' to the circumstances of Aboriginal offenders. The provision could have been more robustly drafted, and there is an argument that this wording contrasts with the more ambitious objectives found in several leading judgments. How might the direction be strengthened? Parliament could have created a rebuttable statutory presumption against the use of imprisonment in cases involving adult offenders.

A third approach would entail a provision to regulate Aboriginal sentencing through the use of criteria which must be fulfilled before a term of custody is imposed. The Youth Criminal Justice Act (YCJA) may provide a useful model in this respect. One of the explicit aims of the YCJA was to reduce the use of custody as a sanction in youth courts, and hence the volume of juvenile admissions to custody. Evaluation research has clearly demonstrated that the YCJA 
achieved a significant decline in the use of custody in youth courts (see Bala et al. 2012). This reduction resulted from creation of different sentencing objectives, principles and disposals, and a similar approach would likely prove successful in the Aboriginal context.

Might sentencing guidelines provide some assistance? Official reports from the 1980s (e.g., Canadian Sentencing Commission 1987; Government of Canada 1984; Canada, House of Commons 1988) as well as academics over the years (e.g., Doob, 1999; Roberts and Bebbington, von Hirsch, Tonry, and Knapp 1987) have recommended the adoption of sentencing guidelines in Canada. In the event that Canada ultimately adopts a guideline scheme, an Aboriginal sentencing guideline would represent another way of reducing the use of custody in cases involving Aboriginal offenders. A guideline applied in cases involving an Aboriginal offender would highlight the factors and considerations that have particular relevance for Aboriginal defendants as well as noting the sentencing options which may be most culturally apposite.

Finally, Parliament could consider adopting sentencing reforms which in themselves do not specifically target Aboriginal offenders, but which would through their application particularly benefit defendants from First Nations. One option would be to reinvigorate and expand the use of alternatives to custody, a reform long advocated (e.g., LaPrairie 1990) and which would be of particular benefit to Aboriginal offenders. A second proposal would amend the $\underline{\text { Code }}$ to direct courts to suspend all terms of custody under a particular threshold - say six months. In 2013-14, fully $87 \%$ of custodial sentences were less than six months; over half were less than one month (Maxwell 2015). The potential of such a reform to achieve a significant reduction in total admissions to custody (and in particular Aboriginal admissions) is therefore very significant. Other jurisdictions have adopted or considered adopting such a reform, in order to reduce the number of short prison sentences more generally. Short prison sentences provide 
little or no opportunity to assist the prisoner, and have deleterious effects on an ex-offender's life and employment opportunities. Similarly, constraining the use of previous convictions as an aggravating circumstance may reduce the number of Aboriginal admissions to custody, as well as the average length of sentence. Aboriginal offenders tend to have longer criminal histories than non-Aboriginals (e.g., Welsh and Ogloff 2008) with the result that a reform of this nature would differentially benefit the former.

\section{Coda}

A generation ago, in 1996, the Royal Commission on Aboriginal Peoples noted in its report that 'the reality for Aboriginal people in 1996 is that the justice system is still failing them.'. The same observation could equally be made in 2016. In Wells, the Supreme Court noted in that 's. 718.2(e) ... was intended to address the serious problem of over-incarceration of Aboriginal offenders in Canadian penal institutions. In singling out aboriginal offenders for distinct sentencing treatment in s. 718.2(e), it is reasonable to assume that Parliament intended to address this social problem.'. Parliament should now be well aware that its promise to Aboriginal peoples remains unfulfilled. On the basis of the data reported here, the inescapable conclusion is that until one of these solutions or some other remedial steps are taken, the problem of Aboriginal over-incarceration will persist. 


\section{References}

Bala, Nick., Peter J. Carrington, and Julian V. Roberts

2012 Implementing youth justice reform: Effects of the Youth Criminal Justice Act. In Youth at Risk and Youth Justice: A Canadian Overview, eds. John Winterdyk and Russell Smandych. Toronto: Oxford University Press.

Balfour, Gillian.

2013 Do law reforms matter: Exploring the victimization-criminalization continuum in the sentencing of Aboriginal women in Canada. International Review of Victimology 19: 85-102.

Canada, Truth and Reconciliation Commission of Canada 2015a Honouring the Truth, Reconciling the Future: Final Report of the Truth and Reconciliation Commission of Canada. Ottawa: Truth and Reconciliation Commission of Canada.

Canada, Truth and Reconciliation Commission of Canada 2015b Calls to Action. Ottawa: Truth and Reconciliation Commission of Canada.

Canadian Sentencing Commission

1987 Sentencing Reform: A Canadian Approach. Ottawa: Supply and Services Canada.

Closing the Gap Clearinghouse

2013 Diverting Indigenous Offenders from the Criminal Justice System: Resource Sheet No. 24. Australian Institute of Health and Welfare, Australian Institute of Family Studies.

Cuneen, Chris

2014 Colonial Processes, Indigenous Peoples, and Criminal Justice Systems. In Oxford Handbook of Ethnicity, Crime and Immigration, eds. Sandra Bucerius and Michael Tonry. Oxford Handbooks Online.

Daubney, David. 1988 Taking Responsibility: Report of the Standing Committee on Justice and Solicitor General on Its Review of Sentencing, Conditional Release and Related Aspects of Corrections (Vol. 65). Ottawa: Queen's Printer for Canada.

Daubney, David and Gordon Parry 1999 An overview of Bill C-41 (the Sentencing Reform Act). In Making Sense of Sentencing, eds. Julian V. Roberts and David P. Cole. Toronto: University of Toronto Press.

Doob, Anthony 1999 Can a Sentencing Commission without power accomplish anything? In Towards a Clear and Just Criminal Law, ed. Don Stuart, Ronald Delisle and Allan Manson. Toronto: Carswell.

Government of Canada

1984 Sentencing. Ottawa: Government of Canada. 
Jeffries, Samantha and Christine Bond 2012a Indigenous disparity in lower court imprisonment decisions: A study of two Australian jurisdictions, 1998 to 2008. Trends and Issues in Crime and Criminal Justice 447: 1-3.

Jeffries, Samantha and Christine Bond

2012b The impact of Indigenous status on adult sentencing: A review of the statistical research literature from the United States, Canada, and Australia. Journal of Ethnicity in Criminal Justice 10(3): 223-243.

Jeffries, Samantha and Philip Stenning 2014 Sentencing aboriginal offenders: Law, policy, and practice in three countries. Canadian Journal of Criminology and Criminal Justice 56(4):

447-494.

Johnston, Elliott

1991 National Report Volume 1. Royal Commission into Aboriginal Deaths in Custody.

LaPrairie, Carol.

1990 The role of sentencing in the over-representation of aboriginal people in correctional institutions. Canadian Journal of Criminology 32(3): 429-440.

Manson, Allan et al.

2008 Sentencing and Penal Policy in Canada. Toronto: Emond Montgomery.

Maxwell, A.

2015 Adult Criminal Court Statistics in Canada, 2013/2014. Catalogue no. 85-002-x. Ottawa:

Statistics Canada.

Murdocca, C.

2013 To Right Historical Wrongs: Race, Gender, and Sentencing in Canada. Vancouver:

University of British Columbia Press.

New Zealand Department of Corrections

2015 Trends in the Offender Population 2014/15. Retrieved on June 9, 2016 from

http://www.corrections.govt.nz/resources/research_and_statistics/offender-volumes-

report/trends_in_the_offender_population_201415.html.

New Zealand Ministry of Justice

1997 Sentencing Policy and Guidance: A Discussion Paper. Wellington: New Zealand Ministry of Justice.

Pelletier, R.

2001 The nullification of section 718.2(e): Aggravating Aboriginal representation in Canadian prisons. Osgoode Hall Law Journal 39: 470-489.

Public Safety Canada 
20152014 Annual Report. Ottawa: Public Safety Canada.

Public Safety Canada

20162015 Annual Report. Ottawa: Public Safety Canada.

Reid, Andrew A.

2016 The (differential) utilization of conditional sentences among Aboriginal Offenders in

Canada. Canadian Criminal Law Review (forthcoming).

Queensland Government

2001 Queensland Aboriginal and Torres Strait Islander Justice Agreement.

Queensland Government

2011 Assessment of the Aboriginal and Torres Strait Islander Justice Agreement 2000-2010.

Roberts, Julian and Howard Bebbington

2013. Sentencing Reform in Canada: Promoting a Return to Principles and Evidence-based

Policy. Canadian Criminal Law Review, 17(3): 327-347.

Roberts, Julian V. and Ronald Melchers

2003 The incarceration of Aboriginal offenders: An analysis of trends, 1978-2001. Canadian

Journal of Criminology and Criminal Justice 45(2): 211-242.

Roberts, Julian V., Joan Nuffield, and Robert Hann

1998 Report of a National Survey on Organized Crime and Corrections in Canada. Ottawa:

Ministry of the Solicitor General.

Royal Commission on Aboriginal Peoples

1996 Bridging the Cultural Divide: A Report on Aboriginal People and the Criminal Justice System in Canada. Ottawa: Supply and Services Canada.

Rudin, Jonathan.

Undated Aboriginal Peoples and the Criminal Justice System. Ipperwash Inquiry.

Rudin, Jonathan.

2013 There must be some kind of way out of here: Aboriginal over-representation, Bill C-10, and the Charter of Rights. Canadian Criminal Law Review 17: 349-364.

Statistics Canada

2015 Youth Correctional Statistics in Canada, 2014/2015. Ottawa: Statistics Canada. Retrieved on June 26 from http://www.statcan.gc.ca/pub/85-002-x/2016001/article/14317-

eng.htm?fpv=2693.

Statistics New Zealand

2015 New Zealand in Profile 2015. Retrieved on June 9, 2016 from

http://www.stats.govt.nz/browse_for_stats/snapshots-of-nz/nz-in-profile-2015.aspx. 
Tonry, Michael.

1997 Ethnicity, crime, and immigration. Crime and Justice. A Review of Research. 21: 1-29.

von Hirsch, Andrew.

1996 Censure and Sanction. Oxford: The Clarendon Press.

von Hirsch, Andrew, Michael H. Tonry, and Kay A. Knapp

1987 The Sentencing Commission and Its Guidelines. Boston: Northeastern University Press.

Walmsley, Roy.

2015 World Prison Population List, Eleventh Edition. London: International Centre for Prison Studies.

Welsh, Andrew and James Ogloff

2008

Progressive Reforms or Maintaining the Status Quo? An Empirical Evaluation of the Judicial Consideration of Aboriginal Status in Sentencing Decisions. Canadian Journal of Criminology and Criminal Justice 50(4): 491-518.

Williams, Toni.

2007 Punishing women: The promise and perils of contextualized sentencing for Aboriginal women in Canada. Cleveland State Law Review 55: 269-287.

\section{Cited Cases}

R. v. Fireman [1971] 3 OR 380 (CA).

R v Gladue, [1999] 1 S.C.R. 688 (SCC).

R v Ipeelee, [2012] 1 S.C.R. 13 (SCC).

R. v. Laliberte, [2000] 4 WWR 491.

R. v Wells, [2000] 1. S.C.R. 207. 
Tables and Figures

Table 1: Admissions to provincial and territorial remand; Canada, 2000-01 to 2014-15

\begin{tabular}{|c|c|c|c|c|c|}
\hline Year & $\begin{array}{l}\text { Non- } \\
\text { Aboriginal } \\
\text { admissions to } \\
\text { remand } \\
\end{array}$ & $\begin{array}{l}\text { Non- } \\
\text { Aboriginal } \\
\text { (period } \\
\text { average = 100) }\end{array}$ & $\begin{array}{l}\text { Aboriginal } \\
\text { admissions } \\
\text { to remand } \\
\end{array}$ & $\begin{array}{l}\text { Aboriginal } \\
\text { (period average } \\
=100 \text { ) }\end{array}$ & $\begin{array}{l}\text { Aboriginal } \\
\text { admissions as } \\
\% \text { of all } \\
\text { admissions } \\
\end{array}$ \\
\hline $2000-01$ & 89278 & 86 & 19490 & 72 & $18 \%$ \\
\hline 2001-02 & 93316 & 90 & 17155 & 63 & $16 \%$ \\
\hline 2002-03 & 95884 & 92 & 18586 & 68 & $16 \%$ \\
\hline 2003-04 & 93058 & 89 & 18698 & 69 & $17 \%$ \\
\hline 2004-05 & 95779 & 92 & 18855 & 69 & $16 \%$ \\
\hline 2005-06 & 114716 & 110 & 27405 & 101 & $19 \%$ \\
\hline 2006-07 & 120112 & 115 & 29202 & 108 & $20 \%$ \\
\hline 2007-08 & 123831 & 119 & 30805 & 113 & $20 \%$ \\
\hline 2008-09 & 121665 & 117 & 32600 & 120 & $21 \%$ \\
\hline 2009-10 & 117984 & 113 & 34915 & 129 & $23 \%$ \\
\hline 2010-11 & 112641 & 108 & 35531 & 131 & $24 \%$ \\
\hline 2011-12 & 110691 & 106 & 37048 & 136 & $25 \%$ \\
\hline 2012-13 & 94267 & 91 & 29080 & 107 & $24 \%$ \\
\hline 2013-14 & 89566 & 86 & 28650 & 106 & $24 \%$ \\
\hline 2014-15 & 87708 & 84 & 29138 & 107 & $25 \%$ \\
\hline Average & 104033 & 100 & 27144 & 100 & $20 \%$ \\
\hline
\end{tabular}

Note: Data are unavailable in New Brunswick, Northwest Territories and Nunavut (2000-01 to 2001-02), Prince Edward Island (2004-05 to 2007-08), Alberta (2000-01 to 2004-05 and 201213 to 2014-15).

Source: Statistics Canada, Adult Correctional Services Survey 
Table 2: Average Aboriginal remand admission percent by province/territory, 2000-01 to 2014-15

\begin{tabular}{lr} 
Province/Territory & $\begin{array}{c}\text { 2000-01 to 2014-15 } \\
\text { Average }\end{array}$ \\
\hline Nunavut & $100 \%$ \\
Northwest territories & $88 \%$ \\
Saskatchewan & $77 \%$ \\
Yukon & $74 \%$ \\
Manitoba & $68 \%$ \\
Alberta & $37 \%$ \\
British Columbia & $24 \%$ \\
Ontario & $10 \%$ \\
Nova Scotia & $10 \%$ \\
Newfoundland/ Labrador & $23 \%$ \\
New Brunswick & $10 \%$ \\
Quebec & $4 \%$ \\
Prince Edward Island & $5 \%$ \\
\hline
\end{tabular}

Note: Data are unavailable in New Brunswick, Northwest

Territories and Nunavut (2000-01 to 2001-02), Prince Edward Island (2004-05 to 2007-08), Alberta (2000-01 to 2004-05 and 2012-13 to 2014-15).

Source: Statistics Canada, Adult Correctional Services Survey 
Table 3: Custodial admission rates and Aboriginal rate-ratio for three federal census years, by jurisdiction.

\begin{tabular}{|c|c|c|c|c|c|c|c|c|c|}
\hline & \multicolumn{3}{|c|}{2001} & \multicolumn{3}{|c|}{2006} & \multicolumn{3}{|c|}{2011} \\
\hline & $\begin{array}{l}\text { non- } \\
\text { Aboriginal } \\
\text { Admission } \\
\text { Rate }\end{array}$ & $\begin{array}{l}\text { Aboriginal } \\
\text { Admission } \\
\text { Rate }\end{array}$ & $\begin{array}{l}\text { Aboriginal } \\
\text { Admission } \\
\text { Rate Ratio }\end{array}$ & $\begin{array}{l}\text { non- } \\
\text { Aboriginal } \\
\text { Admission } \\
\text { Rate }\end{array}$ & $\begin{array}{l}\text { Aboriginal } \\
\text { Admission } \\
\text { Rate }\end{array}$ & $\begin{array}{l}\text { Aboriginal } \\
\text { Admission } \\
\text { Rate Ratio }\end{array}$ & $\begin{array}{l}\text { non- } \\
\text { Aboriginal } \\
\text { Admission } \\
\text { Rate }\end{array}$ & $\begin{array}{l}\text { Aboriginal } \\
\text { Admission } \\
\text { Rate }\end{array}$ & $\begin{array}{l}\text { Aboriginal } \\
\text { Admission } \\
\text { Rate Ratio }\end{array}$ \\
\hline Canada & 1.94 & 11.05 & 5.68 & 2.03 & 15.86 & 7.82 & 1.89 & 17.25 & 9.12 \\
\hline Saskatchewan & 0.80 & 19.05 & 23.93 & 0.80 & 19.67 & 24.66 & 1.06 & 21.19 & 19.95 \\
\hline Manitoba & 0.98 & 13.93 & 14.21 & 1.13 & 14.17 & 12.53 & 1.40 & 22.59 & 16.09 \\
\hline Ontario & 2.63 & 14.75 & 5.60 & 2.47 & 11.47 & 4.65 & 2.26 & 12.36 & 5.48 \\
\hline British Columbia & 1.99 & 11.17 & 5.61 & 1.90 & 10.48 & 5.51 & 1.43 & 12.58 & 8.79 \\
\hline Newfoundland and Labrador & 0.24 & 0.96 & 3.94 & 1.72 & 8.36 & 4.86 & 2.07 & 6.06 & 2.93 \\
\hline Nunavut & 0.00 & 13.25 & --- & 0.00 & 15.45 & --- & 0.00 & 14.99 & --- \\
\hline
\end{tabular}

Note: Rates are calculated per 1000 population.

\section{Footnotes:}

1. 2001 population data were retrieved from archived content published by Statistics Canada and included the following caution: "Information identified as archived is provided for reference, research or recordkeeping purposes. It is not subject to the Government of Canada Web Standards and has not been altered or updated since it was archived. Please contact us to request a format other than those available." (Retrieved from: http://www12.statcan.gc.ca/english/Profil01/AP01/Index.cfm?Lang=E)

2. 2001 population data retrieved from tables published by Statistics Canada included the following footnote: "The Aboriginal identity population is composed of those persons who reported identifying with at least one Aboriginal group, that is, "North American Indian", "Métis" or "Inuit (Eskimo)", and/or who reported being a Treaty Indian or a Registered Indian, as defined by the Indian Act of Canada, and/or who were members of an Indian Band or First Nation.”

3. 2006 population data were retrieved from tables published by Statistics Canada and included the following footnote that applies to Canada, Ontario, Manitoba, Saskatchewan, and British Columbia: “excludes census data for one or more incompletely enumerated Indian reserves or Indian settlements.” (Retrieved from: http://www.statcan.gc.ca/tables-tableaux/sum-som/101/cst01/demo60a-eng.htm)

4. 2011 non-Aboriginal population data were retrieved from tables published by Statistics Canada (Retrieved from: http://www12.statcan.ca/censusrecensement/2011/dp-pd/hlt-fst/pd-pl/Table-Tableau.cfm?LANG=Eng\&T=101\&S=50\&O=A)

5. 2011 Aboriginal population data were retrieved from tables published by Statistics Canada (Retrieved from: https://www12.statcan.gc.ca/nhsenm/2011/as-sa/99-011-x/2011001/tbl/tbl02-eng.cfm) 
Table 4: Provincial variation in Aboriginal admissions to custody, 1978-79, 2000-01, and 2014-15

\begin{tabular}{|l|c|c|c|}
\hline & $\begin{array}{c}\text { Percent of total } \\
\text { admissions } \\
\mathbf{1 9 7 8 - 1 9 7 9}\end{array}$ & $\begin{array}{c}\text { Percent of total } \\
\text { admissions } \\
\mathbf{2 0 0 0 - 2 0 0 1}\end{array}$ & $\begin{array}{c}\text { Percent of total } \\
\text { admissions } \\
\mathbf{2 0 1 4 - 2 0 1 5}\end{array}$ \\
\hline Nunavut & -- & $\mathrm{n} / \mathrm{a}$ & $100 \%$ \\
\hline Northwest territories & $\mathrm{n} / \mathrm{a}$ & $\mathrm{n} / \mathrm{a}$ & $87 \%$ \\
\hline Saskatchewan & $61 \%$ & $72 \%$ & $77 \%$ \\
\hline Yukon & $51 \%$ & $64 \%$ & $72 \%$ \\
\hline Manitoba & $50 \%$ & $n / a$ & $76 \%$ \\
\hline Alberta & $26 \%$ & $20 \%$ & $34 \%$ \\
\hline British Columbia & $15 \%$ & $9 \%$ & $12 \%$ \\
\hline Ontario & $9 \%$ & $7 \%$ & $10 \%$ \\
\hline Nova Scotia & $n / a$ & $7 \%$ & $32 \%$ \\
\hline $\begin{array}{l}\text { Newfoundland/ } \\
\text { Labrador }\end{array}$ & $3 \%$ & $2 \%$ & $3 \%$ \\
\hline Quebec & $1 \%$ & $1 \%$ & $3 \%$ \\
\hline Prince Edward Island & $3 \%$ & $15 \%$ & $26 \%$ \\
\hline Provincial/ Territorial & $15 \%$ & & $n$ \\
\hline Total & & & \\
\hline
\end{tabular}

Notes: Excludes New Brunswick as data are unavailable. Data for Nunavut, Northwest

Territories, Alberta, and Nova Scotia are limited due to unavailable data.

Sources: Adapted from Table 2, Statistics Canada, Adult Correctional Services in Canada, 2013-14 (Ottawa: Statistics Canada, 2015); Roberts and Melchers (2013). 
Figure 1: Aboriginal sentenced admissions as a percentage of all provincial and territorial sentenced admissions, Canada, 1978-79 to 2014-15

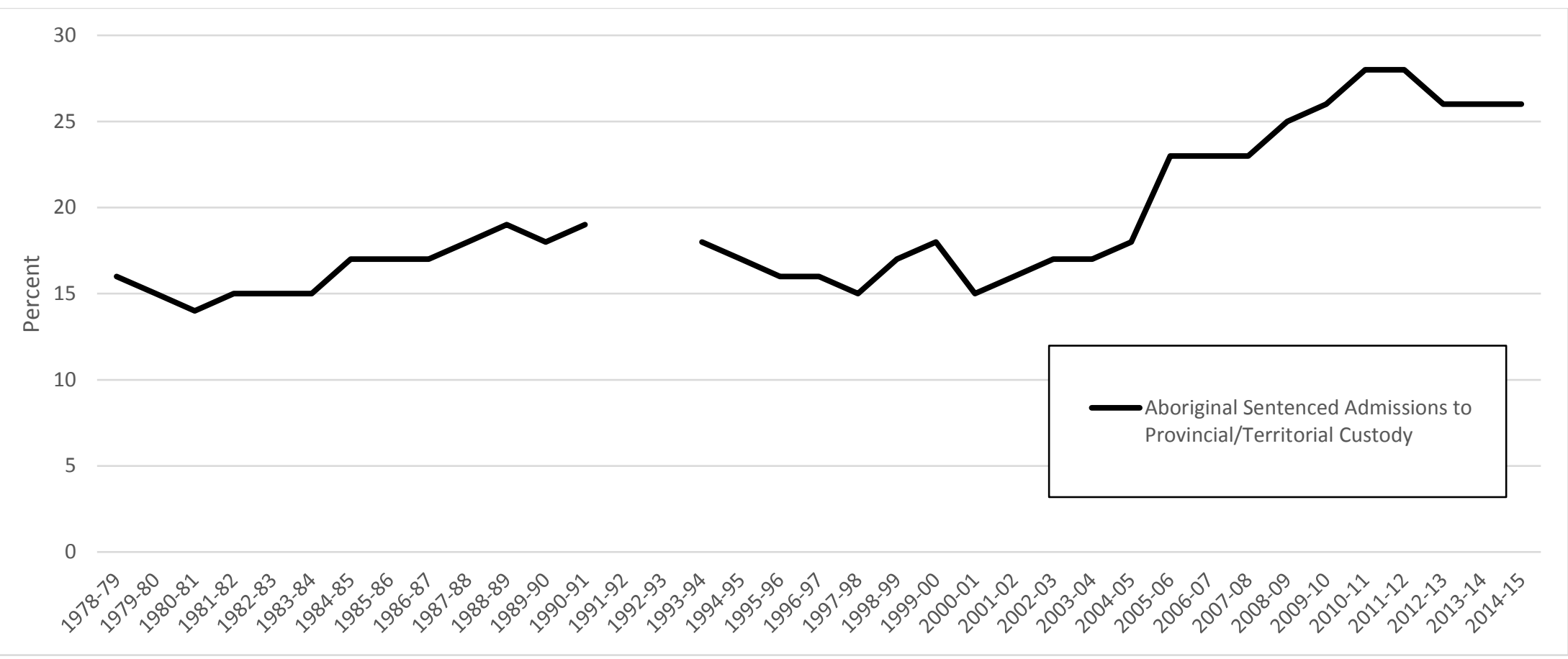

Notes: Excludes New Brunswick as data are unavailable. Data are unavailable in Nunavut and Northwest Territories (2000-01); Alberta (2000-01 to 2004-05); Prince Edward Island (2004-05 to 2007-08). The value for 2000-01 is not the same reported by Roberts and Melchers (2003) as data have been updated by Statistics Canada.

Sources: Adapted from Table 2, Statistics Canada, Adult Correctional Services in Canada, 2013-14 (Ottawa: Statistics Canada, 2015); Roberts and Melchers (2013). 
Figure 2: Percent Federal Aboriginal warrant of committal admissions, Canada, 1978-79 to 2008-09

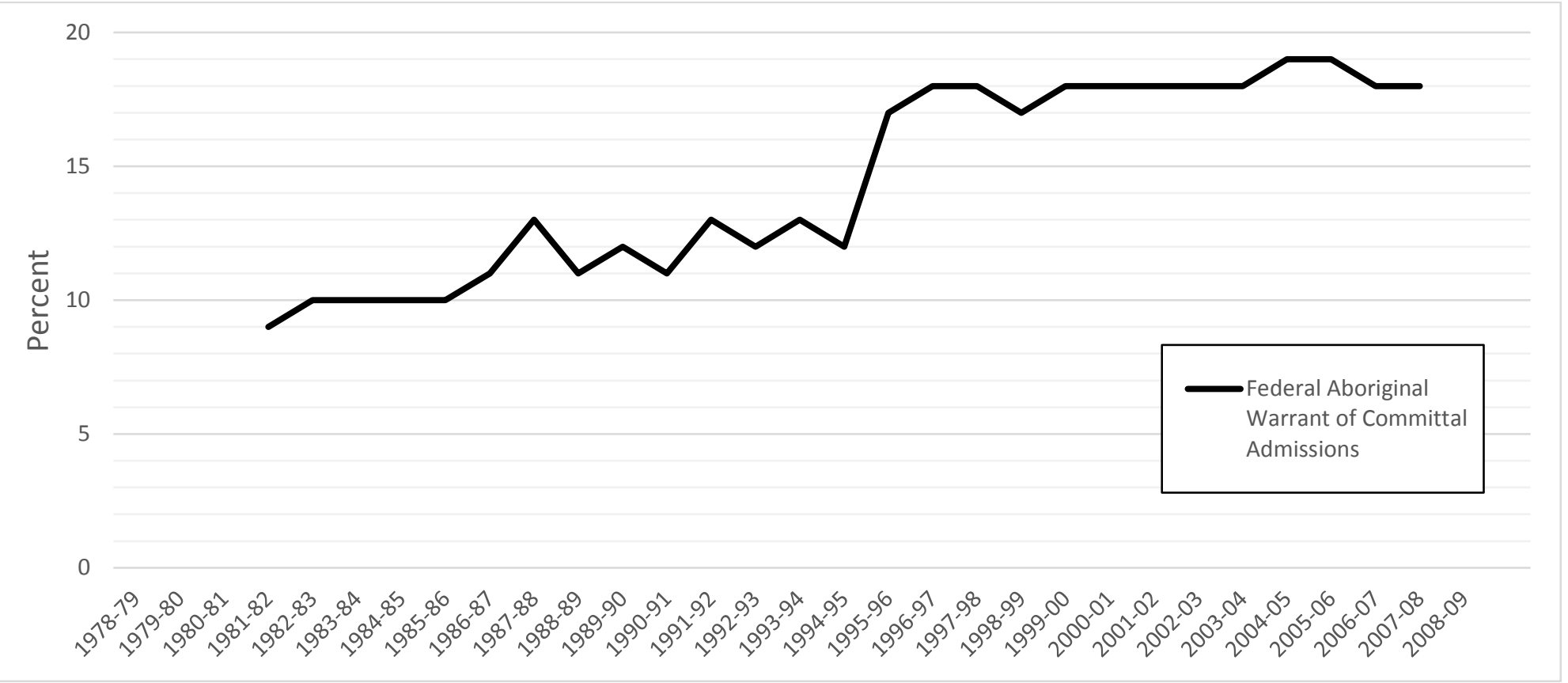

Source: Statistics Canada, Adult Correctional Services Survey 
Table 5: Admissions to provincial and territorial custody; Canada, 2000-01 to 2014-15

\begin{tabular}{|c|c|c|c|c|c|}
\hline Year & $\begin{array}{l}\text { Non- } \\
\text { Aboriginal } \\
\text { admissions to } \\
\text { custody }\end{array}$ & $\begin{array}{l}\text { Non- } \\
\text { Aboriginal } \\
(\text { period } \\
\text { average = 100) }\end{array}$ & $\begin{array}{l}\text { Aboriginal } \\
\text { admissions } \\
\text { to custody }\end{array}$ & $\begin{array}{l}\text { Aboriginal } \\
\text { (period average } \\
=100 \text { ) }\end{array}$ & $\begin{array}{l}\text { Aboriginal } \\
\text { admissions as } \\
\% \text { of all } \\
\text { admissions } \\
\end{array}$ \\
\hline 2000-01 & 55,161 & 98 & 9,603 & 58 & $15 \%$ \\
\hline 2001-02 & 55,733 & 99 & 10,787 & 65 & $16 \%$ \\
\hline 2002-03 & 56,427 & 100 & 11,433 & 69 & $17 \%$ \\
\hline 2003-04 & 53,836 & 96 & 10,920 & 66 & $17 \%$ \\
\hline 2004-05 & 51,438 & 91 & 11,170 & 67 & $18 \%$ \\
\hline 2005-06 & 61,119 & 109 & 18,291 & 110 & $23 \%$ \\
\hline 2006-07 & 61,722 & 110 & 18,597 & 112 & $23 \%$ \\
\hline 2007-08 & 62,310 & 111 & 18,413 & 111 & $23 \%$ \\
\hline 2008-09 & 62,258 & 111 & 20,375 & 123 & $25 \%$ \\
\hline 2009-10 & 61,051 & 108 & 21,789 & 131 & $26 \%$ \\
\hline $2010-11$ & 60,435 & 107 & 23,380 & 141 & $28 \%$ \\
\hline 2011-12 & 60,638 & 108 & 24,161 & 146 & $28 \%$ \\
\hline 2012-13 & 48,902 & 87 & 16,826 & 101 & $26 \%$ \\
\hline 2013-14 & 47,563 & 84 & 16,843 & 102 & $26 \%$ \\
\hline 2014-15 & 45,737 & 81 & 16,309 & 98 & $26 \%$ \\
\hline Average & 56,289 & 100 & 16,593 & 100 & $22 \%$ \\
\hline
\end{tabular}

Source: Statistics Canada, Adult Correctional Services Survey 
Table 6: Sentenced admissions to provincial and territorial custody, Saskatchewan, 2000-01 to 2014-15

\begin{tabular}{|c|c|c|c|c|c|}
\hline Year & $\begin{array}{l}\text { Non- } \\
\text { Aboriginal } \\
\text { admissions } \\
\text { to custody }\end{array}$ & $\begin{array}{l}\text { Non-Aboriginal } \\
\text { (period average } \\
=100 \text { ) }\end{array}$ & $\begin{array}{l}\text { Aboriginal } \\
\text { admissions } \\
\text { to custody }\end{array}$ & $\begin{array}{l}\text { Aboriginal } \\
\text { (period average } \\
=100 \text { ) }\end{array}$ & $\begin{array}{l}\text { Aboriginal } \\
\text { admissions as } \\
\% \text { of all } \\
\text { admissions }\end{array}$ \\
\hline $2000-01$ & 736 & 92 & 2,453 & 84 & $77 \%$ \\
\hline 2001-02 & 663 & 83 & 2,480 & 85 & $79 \%$ \\
\hline 2002-03 & 759 & 95 & 2,739 & 94 & $78 \%$ \\
\hline 2003-04 & 671 & 84 & 2,603 & 89 & $80 \%$ \\
\hline 2004-05 & 779 & 98 & 2,643 & 90 & $77 \%$ \\
\hline 2005-06 & 719 & 90 & 2,659 & 91 & $79 \%$ \\
\hline 2006-07 & 659 & 83 & 2,791 & 95 & $81 \%$ \\
\hline 2007-08 & 622 & 78 & 2,670 & 91 & $81 \%$ \\
\hline 2008-09 & 759 & 95 & 2,811 & 96 & $79 \%$ \\
\hline 2009-10 & 874 & 109 & 3,029 & 104 & $78 \%$ \\
\hline 2010-11 & 924 & 116 & 3,456 & 118 & $79 \%$ \\
\hline 2011-12 & 930 & 116 & 3,343 & 114 & $78 \%$ \\
\hline 2012-13 & 966 & 121 & 3,367 & 115 & $78 \%$ \\
\hline 2013-14 & 910 & 114 & 3,516 & 120 & $79 \%$ \\
\hline 2014-15 & 1,007 & 126 & 3,304 & 113 & $77 \%$ \\
\hline Average & 799 & 100 & 2,924 & 100 & $79 \%$ \\
\hline
\end{tabular}

Source: Statistics Canada, Adult Correctional Services Survey 
Table 7: Sentenced admissions to provincial and territorial custody, Manitoba, 2000-01 to 201415

\begin{tabular}{|c|c|c|c|c|c|}
\hline Year & $\begin{array}{l}\text { Non- } \\
\text { Aboriginal } \\
\text { admissions } \\
\text { to custody } \\
\end{array}$ & $\begin{array}{l}\text { Non-Aboriginal } \\
\text { (period average } \\
=100 \text { ) }\end{array}$ & $\begin{array}{l}\text { Aboriginal } \\
\text { admissions } \\
\text { to custody }\end{array}$ & $\begin{array}{l}\text { Aboriginal } \\
\text { (period average } \\
=100 \text { ) }\end{array}$ & $\begin{array}{l}\text { Aboriginal } \\
\text { admissions as } \\
\% \text { of all } \\
\text { admissions } \\
\end{array}$ \\
\hline 2000-01 & 1047 & 88 & 1854 & 59 & $64 \%$ \\
\hline 2001-02 & 935 & 78 & 2090 & 66 & $69 \%$ \\
\hline 2002-03 & 1070 & 90 & 2246 & 71 & $68 \%$ \\
\hline 2003-04 & 998 & 84 & 2141 & 68 & $68 \%$ \\
\hline 2004-05 & 1050 & 88 & 2458 & 78 & $70 \%$ \\
\hline 2005-06 & 1078 & 90 & 2670 & 85 & $71 \%$ \\
\hline 2006-07 & 1101 & 92 & 2486 & 79 & $69 \%$ \\
\hline 2007-08 & 1104 & 92 & 2506 & 80 & $69 \%$ \\
\hline 2008-09 & 1087 & 91 & 2717 & 86 & $71 \%$ \\
\hline 2009-10 & 1235 & 103 & 3302 & 105 & $73 \%$ \\
\hline 2010-11 & 1373 & 115 & 3955 & 126 & $74 \%$ \\
\hline $2011-12$ & 1421 & 119 & 4425 & 141 & $76 \%$ \\
\hline 2012-13 & 1488 & 125 & 4732 & 150 & $76 \%$ \\
\hline 2013-14 & 1451 & 122 & 4865 & 155 & $77 \%$ \\
\hline 2014-15 & 1471 & 123 & 4758 & 151 & $76 \%$ \\
\hline Average & 1,194 & 100 & 3,147 & 100 & $72 \%$ \\
\hline
\end{tabular}

Source: Statistics Canada, Adult Correctional Services Survey 
Table 8: Sentenced admissions to provincial and territorial custody, Ontario, 2000-01 to 2014-15

\begin{tabular}{|c|c|c|c|c|c|}
\hline Year & $\begin{array}{l}\text { Non- } \\
\text { Aboriginal } \\
\text { admissions } \\
\text { to custody } \\
\end{array}$ & $\begin{array}{l}\text { Non-Aboriginal } \\
\text { (period average } \\
=100 \text { ) }\end{array}$ & $\begin{array}{l}\text { Aboriginal } \\
\text { admissions } \\
\text { to custody }\end{array}$ & $\begin{array}{l}\text { Aboriginal } \\
\text { (period average } \\
=100 \text { ) }\end{array}$ & $\begin{array}{l}\text { Aboriginal } \\
\text { admissions as } \\
\% \text { of all } \\
\text { admissions } \\
\end{array}$ \\
\hline 2000-01 & 28311 & 101 & 2688 & 88 & $9 \%$ \\
\hline 2001-02 & 29203 & 105 & 2777 & 90 & $9 \%$ \\
\hline 2002-03 & 30043 & 108 & 3007 & 98 & $9 \%$ \\
\hline 2003-04 & 28593 & 102 & 2764 & 90 & $9 \%$ \\
\hline 2004-05 & 27978 & 100 & 2758 & 90 & $9 \%$ \\
\hline 2005-06 & 28863 & 103 & 2728 & 89 & $9 \%$ \\
\hline 2006-07 & 29435 & 105 & 2782 & 91 & $9 \%$ \\
\hline 2007-08 & 29803 & 107 & 2980 & 97 & $9 \%$ \\
\hline 2008-09 & 29313 & 105 & 3071 & 100 & $9 \%$ \\
\hline 2009-10 & 28283 & 101 & 3168 & 103 & $10 \%$ \\
\hline 2010-11 & 28104 & 101 & 3578 & 117 & $11 \%$ \\
\hline 2011-12 & 28338 & 101 & 3727 & 121 & $12 \%$ \\
\hline 2012-13 & 26577 & 95 & 3772 & 123 & $12 \%$ \\
\hline 2013-14 & 24388 & 87 & 3336 & 109 & $12 \%$ \\
\hline 2014-15 & 21923 & 78 & 2922 & 95 & $12 \%$ \\
\hline Average & 27,944 & 100 & 3,071 & 100 & $10 \%$ \\
\hline
\end{tabular}

Source: Statistics Canada, Adult Correctional Services Survey 
Table 9: Sentenced admissions to provincial and territorial custody, British Columbia, 2000-01 to 2014-15

\begin{tabular}{|c|c|c|c|c|c|}
\hline Year & $\begin{array}{l}\text { Non- } \\
\text { Aboriginal } \\
\text { admissions } \\
\text { to custody }\end{array}$ & $\begin{array}{l}\text { Non-Aboriginal } \\
\text { (period average } \\
=100 \text { ) }\end{array}$ & $\begin{array}{l}\text { Aboriginal } \\
\text { admissions } \\
\text { to custody }\end{array}$ & $\begin{array}{l}\text { Aboriginal } \\
\text { (period average } \\
=100 \text { ) }\end{array}$ & $\begin{array}{l}\text { Aboriginal } \\
\text { admissions as } \\
\% \text { of all } \\
\text { admissions }\end{array}$ \\
\hline $2000-01$ & 7589 & 112 & 1931 & 83 & $20 \%$ \\
\hline 2001-02 & 7363 & 109 & 1900 & 82 & $21 \%$ \\
\hline 2002-03 & 6848 & 101 & 1723 & 74 & $20 \%$ \\
\hline 2003-04 & 6919 & 102 & 1703 & 73 & $20 \%$ \\
\hline 2004-05 & 7093 & 105 & 1784 & 77 & $20 \%$ \\
\hline 2005-06 & 7162 & 106 & 1871 & 80 & $21 \%$ \\
\hline 2006-07 & 7447 & 110 & 2055 & 88 & $22 \%$ \\
\hline 2007-08 & 7976 & 118 & 2094 & 90 & $21 \%$ \\
\hline 2008-09 & 7115 & 105 & 2424 & 104 & $25 \%$ \\
\hline 2009-10 & 5951 & 88 & 2669 & 115 & $31 \%$ \\
\hline 2010-11 & 5896 & 87 & 2751 & 118 & $32 \%$ \\
\hline 2011-12 & 5967 & 88 & 2922 & 126 & $33 \%$ \\
\hline 2012-13 & 5946 & 88 & 2937 & 126 & $33 \%$ \\
\hline 2013-14 & 6052 & 89 & 2936 & 126 & $33 \%$ \\
\hline 2014-15 & 6325 & 93 & 3193 & 137 & $34 \%$ \\
\hline Average & 6,777 & 100 & 2,326 & 100 & $26 \%$ \\
\hline
\end{tabular}

Source: Statistics Canada, Adult Correctional Services Survey 
Table 10: Sentenced admissions to provincial and territorial custody, Newfoundland and Labrador, 2000-01 to 2014-15

\begin{tabular}{|c|c|c|c|c|c|}
\hline Year & $\begin{array}{l}\text { Non- } \\
\text { Aboriginal } \\
\text { admissions } \\
\text { to custody } \\
\end{array}$ & $\begin{array}{l}\text { Non-Aboriginal } \\
\text { (period average } \\
=100 \text { ) }\end{array}$ & $\begin{array}{l}\text { Aboriginal } \\
\text { admissions } \\
\text { to custody } \\
\end{array}$ & $\begin{array}{l}\text { Aboriginal } \\
\text { (period average } \\
=100 \text { ) }\end{array}$ & $\begin{array}{l}\text { Aboriginal } \\
\text { admissions as } \\
\% \text { of all } \\
\text { admissions } \\
\end{array}$ \\
\hline 2000-01 & 874 & 112 & 70 & 40 & $7 \%$ \\
\hline 2001-02 & 119 & 15 & 18 & 10 & $13 \%$ \\
\hline 2002-03 & 308 & 40 & 71 & 40 & $19 \%$ \\
\hline 2003-04 & 614 & 79 & 131 & 75 & $18 \%$ \\
\hline 2004-05 & 931 & 119 & 154 & 88 & $14 \%$ \\
\hline 2005-06 & 893 & 115 & 154 & 88 & $15 \%$ \\
\hline 2006-07 & 829 & 106 & 196 & 112 & $19 \%$ \\
\hline 2007-08 & 809 & 104 & 200 & 114 & $20 \%$ \\
\hline 2008-09 & 843 & 108 & 172 & 98 & $17 \%$ \\
\hline $2009-10$ & 996 & 128 & 158 & 90 & $14 \%$ \\
\hline 2010-11 & 1026 & 132 & 227 & 129 & $18 \%$ \\
\hline 2011-12 & 992 & 127 & 217 & 124 & $18 \%$ \\
\hline 2012-13 & 855 & 110 & 255 & 145 & $23 \%$ \\
\hline 2013-14 & 833 & 107 & 252 & 143 & $23 \%$ \\
\hline 2014-15 & 771 & 99 & 360 & 205 & $32 \%$ \\
\hline Average & 780 & 100 & 176 & 100 & $18 \%$ \\
\hline
\end{tabular}

Source: Statistics Canada, Adult Correctional Services Survey 
Table 11: Sentenced admissions to provincial and territorial custody, Nunavut, 2000-01 to 201415

\begin{tabular}{|c|c|c|c|c|c|}
\hline Year & $\begin{array}{l}\text { Non- } \\
\text { Aboriginal } \\
\text { admissions } \\
\text { to custody } \\
\end{array}$ & $\begin{array}{l}\text { Non-Aboriginal } \\
\text { (period average } \\
=100 \text { ) }\end{array}$ & $\begin{array}{l}\text { Aboriginal } \\
\text { admissions } \\
\text { to custody } \\
\end{array}$ & $\begin{array}{l}\text { Aboriginal } \\
\text { (period average } \\
=100 \text { ) }\end{array}$ & $\begin{array}{l}\text { Aboriginal } \\
\text { admissions as } \\
\% \text { of all } \\
\text { admissions } \\
\end{array}$ \\
\hline 2000-01 & --- & --- & --- & --- & --- \\
\hline 2001-02 & 0 & 0 & 301 & 79 & $100 \%$ \\
\hline 2002-03 & 0 & 0 & 314 & 82 & $100 \%$ \\
\hline 2003-04 & 0 & 0 & 269 & 71 & $100 \%$ \\
\hline 2004-05 & 0 & 0 & 279 & 73 & $100 \%$ \\
\hline 2005-06 & 0 & 0 & 409 & 107 & $100 \%$ \\
\hline 2006-07 & 0 & 0 & 385 & 101 & $100 \%$ \\
\hline 2007-08 & 0 & 0 & 336 & 88 & $100 \%$ \\
\hline 2008-09 & 1 & 350 & 376 & 99 & $100 \%$ \\
\hline 2009-10 & 0 & 0 & 400 & 105 & $100 \%$ \\
\hline 2010-11 & 0 & 0 & 386 & 101 & $100 \%$ \\
\hline 2011-12 & 0 & 0 & 410 & 108 & $100 \%$ \\
\hline 2012-13 & 1 & 350 & 417 & 109 & $100 \%$ \\
\hline 2013-14 & 2 & 700 & 549 & 144 & $100 \%$ \\
\hline 2014-15 & 0 & 0 & 504 & 132 & $100 \%$ \\
\hline Average & 0 & 100 & 381 & 100 & $100 \%$ \\
\hline
\end{tabular}

Note: Data are not available for 2000-01.

Source: Statistics Canada, Adult Correctional Services Survey 


\section{Notes}

${ }^{1}$ The authors are grateful to the anonymous reviewers of the journal for helpful comments on a previous draft.

${ }^{2}$ For an early example (1971) of a court addressing the sentencing of an Aboriginal offender see R. v. Fireman.

${ }^{3}$ The Commission called for enhanced cultural competency training for lawyers, and for federal, provincial and territorial governments to 'commit to eliminating the overrepresentation of Aboriginal people in custody over the next decade’ (Canada, 2015b p.3). Yet few specific solutions were offered which directly invoke the sentencing process. The calls to action were aspirational rather than practical in nature. In fact, only two clear proposals were made. First, the report urges governments to 'provide stable and sufficient funding to implement and evaluate community sanctions that will provide realistic alternatives to imprisonment for Aboriginal offenders'. Second, the federal government is encouraged to allow courts to depart from mandatory minimum sentences and restrictions on conditional sentences. Both reforms are to be welcomed; neither will effectively or expeditiously reduce the rate of Aboriginal admissions to custody.

${ }^{4}$ For an exchange of contrasting views, see the colloquy on the subject contained in volume 65, number 2 of the Saskatchewan Law Review.

${ }^{5}$ The conditional sentence has a statutory 'ceiling' of two years less one day, with the result that offenders sentenced to a term of imprisonment in excess of this are ineligible.

${ }^{6}$ The percentage of all admissions involving an Aboriginal person is calculated using the count of Aboriginal sentenced admissions as the numerator and the sum of Aboriginals and non-Aboriginals as the denominator. As a result, this measurement does not include sentenced admissions where the Aboriginal identity of an offender is unknown.

${ }^{7}$ Although the conditional sentence of imprisonment (CSI) is, as the term implies, a term of imprisonment we do not include conditional sentence offenders in our analysis. Data trends are less reliable for the CSI, and following a number of legislative amendments in recent years the CSI accounts for a very small percentage of sentenced cases.

${ }^{8}$ The most recent data from Statistics Canada reveal that there were almost 6,000 Aboriginal youth admitted to correctional services in nine jurisdictions in 2014/2015. This represented one-third of all admissions while Aboriginal youth (aged 12 to 17) account for about 7\% of the youth population in the nine reporting jurisdictions (Statistics Canada 2015).

${ }^{9}$ http://www12.statcan.gc.ca/nhs-enm/2011/as-sa/99-011-x/99-011-x2011001-eng.cfm.

${ }^{10}$ Aboriginal over-incarceration is one of the few correctional problems of which the public seem aware. A nationwide survey conducted almost 20 years ago found that when asked to estimate the percentage of prisoners who were Aboriginal the median estimate from the public was 20\% (Roberts, Nuffield, and Hann 1998).

${ }^{11}$ At the federal level, the category 'Aboriginal' includes persons who have classified themselves as Innuit, Innu, Metis and North American Indian. 
${ }^{12}$ See for example para 69 of the judgement R. v. Laliberte, [2000] 4 WWR 491, and discussion in Manson et al. (2008), Chapter 16.

${ }^{13}$ We use the word 'potentially' because a small yet unknown number of these annual admissions involve the same individual being re-admitted to custody (see text). 1/11 